378.147::811.163.41(450)

https://doi.org/10.18485/msc_saopstenja.2018.48.1.ch12

Љиљана М. БАЊАНИН*

Università degli Studi di Torino
Прегледни рад

Примљен: 15. 10. 2018.

Прихваћен: 03. 12. 2018.

\title{
О ЛЕКТОРАТИМА У ИТАЛИЈИ: ОД СРПСКОХРВАТСКОГ ДО СРПСКОГ И ХРВАТСКОГ - ИСТОРИЈАТ, СТАҢЕ, ПЕРСПЕКТИВЕ
}

\begin{abstract}
Тема реферата су лекторати нашег језика као саставни део славистичких студија на италијанским универзитетима. У уводном делу понудили смо кратак историјски преглед изучавања нашег језика у оквиру лектората при универзитетским славистичким центрима у другој половини 20. века. Затим указујемо на терминолошку еволуцију условљену распадом некадашњег стандарда, што је утицало и на лекторате. Пажња је посвећена и функцији лектората, академском и правном статусу лектора и профилу ове категорије у италијанском универзитетском систему.

Циљ је да се прегледно и документовано прикаже где се у Италији предаје наш језик. Мапирањем прикупљених података и њиховом анализом стећи ће се слика тренутног стања и добити увид у реалну ситуацију о маргиналном положају српског језика у формативној понуди италијанских универзитета, а на основу тога ће се извести закључци о перспективи у будућности.

Кључне речи: италијанска славистика, универзитети, лекторати, реформа универзитета, разменски лектори, стални лекторати, хонорарни лектори, српски језик.
\end{abstract}

\section{Увод: србистика као део славистике}

Када се говори о италијанској славистици и положају српског језика у Италији, дотичемо се питања које никада раније, а чак ни последњих деценија, када је постало актуелно, у Србији није изазивало неко посебно интересовање. Због тога су радови у чијем су фокусу ове теме малобројни, чак и ако се узму у обзир они чији су аутори професори на италијанским универзитетима (Стипчевић 2007; Бањанин 2007, 2009; Лазаревић Ди Ђакомо 2012). То је заправо одраз давно укорењеног става да је италијанска славистика,

*1jiljana.banjanin@unito.it 
па и сербокроатистика, по научним резултатима заостала далеко иза неких других, из српске перспективе важнијих националних славистика, пре свега руске, пољске и немачке на пример. Један од могућих разлога овог „општег места" треба, према нашем мишљењу, тражити у конципирању, манифестовању и практичној организацији славистике. Док се у европским земљама ишло ка специјализацији у појединим гранама, италијанска славистика је, од својих почетака (двадесетих година 20. века) па све до данас, остала један врло „густо” насељен научно-дисциплинарни сектор који се у министарским документима обележава сиглом „L-LIN/21 Slavistica”.

Италијанска славистика обухвата све словенске језике и њихове књижевности: белоруски, бугарски, чешки, македонски, пољски, руски, српскохрватски (односно БХМС), словачки, словеначки, украјински и црквенословенски, са свим варијантама, као и синхронијску и дијахронијску димензију разних истраживачких аспеката и теорије превођења. ${ }^{1}$ Као што примећује Лазаревић Ди Ђакомо, „оваква административна дефиниција може да представља извесне проблеме у пракси, па приликом отварања нових радних места нису искључена извесна 'изненађења"” (Лазаревић Ди Ђакомо 2012: 274). Ако је, на пример, одређеном факултету потребан стручњак за српскохрватски језик и књижевност, према закону је могуће да то место добије слависта стручњак за руски или словеначки, јер се на конкурсима не вреднује поље истраживања него научни рад појединог кандидата / истраживача. Ово је једна од последица аутономије универзитета - које могу да се посматрају на позитиван или негативан начин - али свакако утиче и на организацију наставе и одабир наставног кадра, па и лектора, који су, од увођења овога звања па до данас, у тесној вези са наставом језика. Њу је из темеља уздрмала и трансформисала реформа универзитета која је у Италији званично уведена 1999, а ступила на снагу академске године 2000/2001.

Пре тога, референтни професор бавио се готово искључиво књижевношћу, ${ }^{2}$ док је лекторима, на чији ћемо се историјат укратко осврнути у наставку, у потпуности била поверена брига о дидактици језика. Наш предмет звао ce Lingua e letteratura serbo-croata (Српскохрватски језик и књижевност), постојао је у табелама појединих факултета и могао да се одабере као главни предмет студија, али је најчешће био помоћни / изборни предмет, са трајањем од једне или, најчешће, две студијске године, који је требало да допринесе комплетном формирању дипломираних слависта којима је основна студијска група била руски језик и књижевност. Слаба понуда дидактичких материјала, заснованих пре свега на застарелим моделима пасивног учења страног језика, али и превласт писменог превођења као привилегованог дидактичког проседеа, условљавали су да се језику придаје сасвим мали значај.

Реформа универзитета довела је до великих промена у систему студирања, не само због преласка са четворогодишњих блиндираних, тј. факултетским програмима предодређених студијских програма, на трогодишње

\footnotetext{
${ }^{1}$ O томе опширније у: Лазаревић Ди Ђакомо 2012: 274.

${ }^{2} \mathrm{O}$ историјату сербокроатистике на италијанским универзитетима опширније у: Бањанин 2007.
} 
и специјалистичке / мастер двогодишње слободне студије (тзв. $3+2)$, него и због удвајања предмета. Језик је одвојен од књижевности, тако да су референтним наставницима (редовним и ванредним професорима и истраживачима / доцентима) поверена два предмета: језик и књижевност. ${ }^{3}$ Тиме на плану дидактике језик добија привилегован положај, придаје се већи значај његовој функционалности, употребљивости, а мења се и улога лектора. Професор / наставник своје монографске, теоријске курсеве (54 до 60 сати у семестру) усредсређује на одређене сегменте (морфологија, синтакса, теорија превођења, специфични / струковни језик), док је лектор тај који студенте треба да доведе до одређеног нивоа познавања и употребе језика, предвиђеног Европским језичким оквиром. У односу на раније периоде, и дидактички материјал се усавршио и модернизовао, а увођење европских програма мобилности и разних облика сарадње омогућава студентима да знање језика усаврше и на лицу места, тј. у земљи чији језик уче.

Од лингвистичког порекла и опредељења лектора, као што је и разумљиво, зависила је, и зависи, варијанта која се привилегује или јој се придаје већи или искључиви значај у настави. Ова чињеница умногоме ће утицати на касније профилисање лектората нашег језика у Италији. Назив lingua serbocroata, serbo-croata (са цртицом или без ње) формално се задржао све до данас, мада постоје и варијанте lingua serba e croata, које су усвојили многи универзитети; на предлог удружења италијанских слависта (AIS), у назив су од 2017. укључени и босански и црногорски / монтенегрински (BCMS), који се, ипак, још увек не јављају у званичном називу ни на једном италијанском универзитету. Ова неприметна еволуција у називу рефлектује, на неки начин, политичко стање у односима између Италије и њених суседа, Југославије и новонасталих земаља, које је условило декомпозицију и множење не само назива језика него и његову практичну суштину (уп. Морабито 2006).

\section{Типологија лектората и профили лектора}

Од 1940. године и оснивања прве катедре за српскохрватски језик и књижевност на Универзитету у Падови, чији је оснивач и шеф био Артуро Кронија [Arturo Cronia], региструје се појава сербокроатиста, специјализованих слависта, за разлику од поливалентних филолога који су се, дотад, само узгредно и маргинално бавили нашим темама. Интензиван рад Јоланде Маркијори [Jolanda Marchiori] у Падови и Лилиане Мисони [Liliana Missoni] на Оријенталном институту у Напуљу наставља се путем претежно књижевних истраживања која је започео „маестро” Кронија, и доказ је великог полета италијанске сербокроатистике и њеног стабилизовања као славистичке гране, шездесетих и седамдесетих година 20. века. То је ипак још увек фаза у којој су истраживања и настава усмерени или претежно на филологију, тј. на

\footnotetext{
${ }^{3}$ Ова реформа позната је као једна од најекономичнијих јер је изведена са постојећим кадром.
} 
историјску упоредну граматику словенских језика, или на изучавање књижевности.

Године 1960, 3. децембра, у Риму је потписан споразум између владе Републике Италије и СФРЈ о сарадњи у области културе, науке и образовања, који је обновљен 1980. године. Ови споразуми, али и све веће присуство, утицај и ширење Европске уније, неминовно су довели до интензивније међународне комуникације, што је на италијанским универзитетима резултирало новим сазнањима о важности и улози страних језика и њиховој практичној примени, па се, сходно томе, мења и концепција наставе страних језика - до тада углавном везана за традиционалне методе чији је циљ био писмени превод литерарних текстова.

И поред тога што су на многим универзитетима постојале катедре за славистику, а при њима и сербокроатистика, није постојао систематски организован рад лектората нашег језика на италијанским универзитетима. Неки облици лекторских функција спорадично или континуирано су постојали на многим катедрама, и као пример наводимо два универзитета, која не припадају великим славистичким центрима, али на којима се наш језик предаје и постоји континуирано, од касних шездесетих година у Торину, односно од 1978. у Удинама.

Са формирањем специјализованог наставничког кадра уочава се важност учења језика, као и улога и присуство изворних говорника. Осим тога, и захваљујући званичним међудржавним уговорима између Италије и Југославије, јавља се звање разменских лектора. Такви уговори, и са другим државама, омогућили су да наша бивша земља Југославија, преко Завода за међународну, просветну, научну и техничку сарадњу, а доцније Одељења за међународну сарадњу при Министарству просвете, води бригу о лекторатима српскохрватског језика у свету. Лектори су бирани путем конкурса и упућивани на разне европске универзитете, па и на италијанске: у Падову, Милано, Фиренцу, Бари и на Сапијенцу у Риму. То су били најчешће асистенти или млађи доценти, редовно запослени на домаћим универзитетима / факултетима, који су у иностранству проводили обично три године. Њихов статус био је изједначен са статусом тадашњих асистената на иностраним факултетима. При одабиру се строго водило рачуна о ротацији, која је укључивала све бивше социјалистичке републике, при чему подвлачимо чињеницу да су у Италију били упућивани лектори из оних универзитетских центара са добром италијанистичком традицијом, а то су били пре свега Загреб и Београд. Ово показује да је постојала смишљена политика: с једне стране имала се у виду важност улоге лектора као културног амбасадора матичне земље а, с друге, били су то увек врсни стручњаци, италијанисти који су били обучени да делају као лингвистички компаратисти.

Потврду да је у Југославији постојала свест о важности улоге лектора представља и податак да је са загребачког универзитета као лектор у Фиренци, на хуманистичком факултету (Facoltà di Lettere) и на факултету политичких наука, 1954/55. радио Иван Франгеш. Кад се он вратио у Загреб да, после смрти Антуна Барца, преузме катедру, на његово место су 1956/57. и 1957/58. 
дошли Иван Сламниг и Никола Миличевић.. ${ }^{4}$ Ова места су, и после тога, увек поверавана изузетним стручњацима: на истом универзитету лектор је био Иван Клајн, а после њега и многи други: на пример, осамдесетих година Олга Кисић, а 1990-1992. писац Милисав Савић, који је као лектор провео неколико година и у Милану. Ту је, од 1973. до 1975, као лектор српскохрватског језика на Државном и на Католичком универзитету радио и слависта, песник и преводилац Јоја Рицов, а 1979/80. врсни италијаниста Тонко Мароевић, ${ }^{5}$ после њега Лидија Вукичевић, такође песникиња и прозаиста.

На престижној Сапијенци у Риму као лекторке су биле Гордана Терић (1984-1986), Милана Пилетић (1986-1987), са Београдског, и Весна Килибарда (1987/88. и 1989/90) са Никшићког универзитета, која је дипломирала на београдском Филолошком а докторирала на загребачком Филозофском факултету.

У Барију су на сербокроатистичкој катедри, на чијем је челу био Франческо Саверио Перило [Francesco Saverio Perillo], као лектори радили београдски италијаниста Жељко Ђурић $(1991 / 92,1992 / 93)$ и Весна Килибарда (1998/99, 1999/2000), али и хрватска италијанисткиња Сузана Главаш, која је касније прешла у Напуљ, док је у Барију место ванредног професора од школске 1999/2000, низ година потом, покривала Светлана Стипчевић. За то време и неколико лектора радило је у Барију, а најдуже се задржао италијаниста и преводилац Драган Мраовић.

У Падови, која је традиционално одржавала добре везе са загребачким универзитетом, Јоланда Маркијори успоставила је контакте и са Сарајевом, те је у периоду 1987-1990. као разменски лектор тамо радила Љиљана Бјелица, са Сарајевског универзитета, да би од 1993. па до 2017. она постала стални лектор у Риму. У Падови је у периоду 1990/91. и 1991/92, до ембарга, лектор била Мирка Зоговић са Филолошког факултета у Београду, а после ње ово место заузимали су искључиво лектори из Хрватске.

Паралелно с овим наставничким позицијама, са отварањем нових радних места и славистичких центара, законом из 1980. године (Legge 382/1980) омогућено је отварање и нових лекторских места за која поједини универзитети, у зависности од својих потреба али и економских могућности, бирају и запошљавају кадар путем интерног конкурса. Њихов правни статус другачији je у односу на разменске лекторе (регулисане уговорима на државном нивоу). Све до деведесетих година ови лектори имали су уговоре који су варирали од универзитета до универзитета.

Запослени као стручна лица и слободни префесионалци, али без регулисаног радног стажа и социјалне заштите (што су самостално морали да обезбеде), ови лектори морали су да испуњавају одређене услове - пре свега да буду изворни говорници са високом стручном спремом и искуством у на-

\footnotetext{
${ }^{4}$ За драгоцене податке који се односе на лекторе из Хрватске захвалност дугујемо проф. др Сањи Роић са загребачког Филозофског факултета.

${ }^{5}$ Тонко Мароевић спевао је и сонете Makar makaronski (Sonetti milanese) iliti mala lektorska kronika šk. god. 1980/81. na Sveučilištu u Milanu (Maroević 1992: 81-88), у којима је ведро, хуморно и зналачки описао своје искуство са италијанским студентима.
} 
стави. Нису, међутим, имали ексклузивну обавезу према матичном универзитету, што значи да су професионално могли да се баве и другим пословима, као што је настава у школама, превођење и сл. У оквиру универзитетске организације, ова лица нису била укључивана у комисије или радне групе, сем оних које су биле везане искључиво за испите из језика. Новим законом, који је ступио на снагу 21. јуна 1995. године (бр. 236), лектори постају $C E L$ (collaboratori ed esperti linguistici), тј. језички / лингвистички сарадници и стручњаци, а њихов правни статус регулише се уговором на националном нивоу, који им обезбеђује сва права, али и обавезе предвиђене законом. Дакле, сада ова лица имају пре свега уговор на неодређено време, који их штити правно и економски: добијају тринаест месечних плата годишње, имају право на тридесет дана одмора, као и потпуну социјалну и здравствену заштиту. Број сати које су ови лектори дужни да према уговору остваре, достиже годишњи максимум од 500 сати, у неким случајевима 400, или, врло ретко, и мање. У тај број урачуната је настава (највише 12 сати седмично), припрема за наставу, консултације (један сат седмично), присуствовање испитима и припрема писмених / усмених испита. Ипак, положај ових сарадника ни до данас није јасно дефинисан: њихов статус изједначен је са техничко-административним персоналом, где се разликују профили са универзитетском дипломом или без ње. Најкритичнију тачку у изједначавању ових лектора са универзитетским наставним кадром представља чињеница да на факултетско радно место нису примљени преко националног конкурса и компаративне селекције, него путем интерног конкурса - који сваки факултет расписује појединачно, са интерном комисијом а не министарском, не на националном нивоу.

Лекторат за српскохрватски језик овог типа постоји, у Торину, континуирано од 1983, затим у Удинама, где садашња лекторка Љерка Хофман ради у звању лингвистичког експерта, од 2001/2002; у Трсту од 1995. као стални лектор ради редовна професорка Загребачког свеучилишта Сања Роић, а у Венецији од исте године Александра Младеновић. У Ђенови је веома кратко постојао лекторат за наш језик, али се угасио, као и у Барију. У Пескари такође постоји стални лектор (Јасмина Пајтак), док је ситуација нешто другачија у Фиренци, где је лекторат спорадичан, као и у Форлију, истуреном одељењу универзитета у Болоњи. Стални лектор постоји и у Напуљу (Сузана Главаш), а у Риму је, с одласком у пензију Љиљане Бјелице 2017, место лектора остало упражњено све до недавно.

Осим ових стабилизованих лектора, последњих година се све чешће на одређено време, са редовним уговорима и с неуједначеним бројем сати, у трајању од обично годину дана - ангажују лектори којима није загарантован ни континуитет у настави а ни економска стабилност. Ова места слабије су плаћена, а реч је, у суштини, о искоришћавању висококвалификоване радне снаге. На појединим италијанским универзитетима - на Високој школи за преводиоце у Трсту, у Падови и у Риму - постоји и лекторат за хрватски језик, који финансира хрватска држава. На ово је пре више од десет година указала Светлана Стипчевић: 
[...] Хрватска, међутим, спровела је после 1991. године праву културну револуцију која је захватила све хрватске лекторате у свету, па и у Италији. Тамо где није било друге могућности, то јест могућности размене лектора, они су се попуњавали лекторима које је плаћала сама хрватска држава. Почетком 2000. године, у Италији је Хрватска имала осам лектората, пет је самофинансирала, а три је имала на размени. Дакле, готово да није било ниједне србокроатистичке катедре где није било хрватског лектората (Стипчевић 2007: 261).

Значи, са распадом Југославије, а као директна последица ембарга и признања Хрватске од стране Немачке, Ватикана и Италије, упражњена места попуњавају се хрватским лекторима, о чему смо и ми писали, указујући на неуједначеност у односу на лекторе са српског говорног подручја (Бањанин 2007). Ако је ситуација 2007. године показивала бројчану предност хрватских лектората (два лектора у Трсту, на Факултету хуманистичких наука и на високој школи за преводиоце и тумаче, у Удинама, Падови, Милану, Фиренци, Форлију, Пескари, Риму, Напуљу) у односу на српске (Венеција, Торино, Ђенова, Рим, Бари), она је данас готово незнатно измењена када су у питању хрватски лекторати, док су српски у нестајању. На овај негативан тренд утицала је пре свега чињеница да су лекторати везани за постојање наставничких места: где њих нема, нема ни лектората. То се десило са лекторским местом у Ђенови, које је било хонорарног типа, на одређено време, али је постојало све док је као хонорарни професор радио Силвио Ферари [Silvio Ferrari]. Слично је било и са местом у Барију: тамо ради професор славистике Барбара Ломађистро [Barbara Lomagistro], која се бави и србистичким темама али је референтни наставник за славистику и за јужнословенске језике и књижевности (српску, хрватску, бугарску), као и за словенску филологију, и покрива велики број предмета. У Риму су лекторати „удвојени”, постоји хрватски и српски, после смрти Лионела Костантинија [Lionello Costantini] 1994, у време када је као редовни професор на престижној Сапијенци био Предраг Матвејевић. Од тада званично постоји лекторат за хрватски језик, који финансира хрватско министарство, док је Љиљана Бјелица покривала српски, све до свог одласка у пензију. И овде постоји референтни професор славистике који покрива јужнословенске језике и књижевности Јања Јерков, али је активан само хрватски лекторат.

\section{Закључак}

На основу свега наведеног можемо да констатујемо да је сербокроатистика заступљена на бројним италијанским универзитетима на читавој територији државе. Пре десетак година оптимистички смо указали на позитиван тренд србистичких научних истраживања на италијанским универзитетима, који и данас постоји, али првенствено захваљујући научној активности наставника који се баве српским темама; томе не одговара и престиж нашег језика, што је прегледно и статистички документовано: ослањајући се на податке, чињеница је да је 2011. српскохрватски језик био један од најпрестижнијих, одмах после руског (Бањанин 2007; Лазаревић Ди Ђакомо 2012), а да- 
нас се ситуација знатно променила - наш језик је у опадању не само у односу на пољски, на пример, него и у односу на словеначки, који је учврстио своје позиције како на постојећим тако и на новим местима наставника и лектора, које подржава држава Словенија. Стални лекторати српског језика постоје тренутно једино на венецијанском универзитету Ка Фоскари (Са' Foscari) и у Торину, на Департману за стране језике и књижевности (Dipartimento di LLSCM), док су хрватски присутни у Трсту, Удинама, Падови, Фиренци, са повременим курсевима и у Форлију, Пескари, Риму и Напуљу.

Већ смо указали на то да је Хрватска спремније дочекала како политичке, друштвене, социјалне промене после распада Југославије, тако и реформу универзитетских студија, што се рефлектује и бригом о сопственом језику у иностранству - он се негује и о њему се системски и систематски води брига. Доказ томе није само спремност да се финансирају лекторати, да се организују и економски и стручно подржавају курсеви хрватског језика на свим нивоима, почев од предшколског узраста па до студентске популације, него и активно присуство државе преко конзуларних представника на манифестацијама које укључују хрватску културу, књижевност, језик, спорт. Ако нам се допусти да се критички осврнемо на присутност Србије на италијанским универзитетима, рекли бисмо да је чињеница да не постоји координација на државном нивоу, већ би контакти могли да се окарактеришу као изолована иницијатива појединаца и/или институција. Тако, рецимо, деценијама веома добро функционише сарадња Народне библиотеке, Универзитетске библиотеке из Београда и Библиотеке Матице српске из Новог Сада са свим универзитетима. Ове српске институције најновијим издањима србистичке али и кроатистичке литературе опскрбљују факултетске / департманске библиотеке на италијанским универзитетима, што је добар пример културне пропаганде. Током претходних година са иностраним факултетима сарађивале су, и сарађују, и друге институције. Овде имамо на уму сарадњу са различитим установама, као и скупове које организује Филолошки факултет са својим центрима - МСЦ-ом, Центром за српски као страни, затим стипендије које студентима на основним, магистарским и докторским студијама редовно додељују МСЦ, Филозофски факултет у Новом Саду и Министарство просвете Републике Србије.

Мишљења смо да би, уза све ово, ротација универзитета који би примали стране студенте била двоструко корисна. С једне стране, ово би омогућило да се страни студенти упознају са целом Србијом а, са друге, оваква сарадња била би корисна и самим универзитетима, због повратних искустава. При томе би требало водити рачуна да се предност у стипендијама да̂ студентима који долазе са оних, малобројних, универзитета на којима се негује пре свега српски језик.

На самом крају, из данашње перспективе а са десетогодишње временске дистанце, још увек је актуелан апел који је 2007. године С. Стипчевић упутила свима којима је у нашој средини стало до српског језика, наглашавајући да je ,последњи [...] тренутак, барем када је судбина српског језика у Италији у питању, а [...] не би шкодило ни када су у питању друге земље, да се сачини 
нека врста акционог плана [...] који би био део једног широко замишљеног и добро осмишљеног програма српске културне промоције у иностранству" (Стипчевић 2007: 262). Он би требало да обухвати најважније српске институције у земљи и иностранству (министарства, САНУ, универзитете, институте, библиотеке, дипломатска представништва), стратегију отварања лектората и свесну бригу о лекторима и њиховом оспособљавању за наставу српског језика као страног, са познавањем језика земље у којој ће радити. Показало се, наиме, у пракси, да универзитетска диплома није довољан услов који гарантује да је лектор стручњак за српски језик. Од лектора се траже и други квалитети: пре свега мотивисаност, комуникативност и самосвест да је најважнија функција лектора у иностранству да буде спона између две средине, две културе, два језика, и нека врста културног амбасадора.

\section{ЛИТЕРАТУРА}

Бањанин 2007: Љ. Бањанин, Лекторати српскохрватског / српског језика у Италији: историјат, стање, перспективе, у: Српски као страни језик у теорији и пракси, прир. М. Дешић, Београд: Филолошки факултет, Центар за српски као страни, 267-276.

Бањанин 2009: Љ. Бањанин, Настава језика као Л2 у светлу реформисаних студија, у: Индивидуализачија и диференцијащија у настави језика и књижевности, прир. Ј. Вучо, Б. Милатовић, Никшић: Филозофски факултет, 406-414.

Лазаревић Ди Ђакомо 2012: П. Лазаревић Ди Ђакомо, Савремено академско проучавање јужнословенских језика и књижевности у Италији, у: Савремено друштво и криза проучавања језика и књижевности, прир. М. Ковачевић, Д. Бошковић, Крагујевац: Филолошко-уметнички факултет, 273-297.

Мароевић 1992: T. Maroević, Sonetna struka. Crteži Z. Keser, Zagreb: Hrvatska sveučilišna naklada.

Морабито 2006: R. Morabito, La situazione linguistica attuale nell'area a standard neoštokavi (ex-serbo-croato), Firenze: Studi Slavistici III, 297-350.

Поповић 2007: Г. Поповић, Судбина српског језика у Италији, Београд: Политика, 2. 4. 2007. (Интервју са Светланом Стипчевић - www.politika.rs)

Стипчевић 2007: С. Стипчевић, Српски у Италији, у: Српски као страни језик у теорији и пракси, прир. М. Дешић, Београд: Филолошки факултет, Центар за српски као страни, 255-265.

Стипчевић 2008: S. Stipčević, Srpska književnost i srpski jezik u svetlu italijanske književne istoriografije, y: A. Alberti, S. Garzonio, N. Marcialis, B. Sulpasso (a cura di), Contributi italiani al XIV Congresso Internazionale degli Slavisti (Ohrid, 10-16 settembre 2008), Firenze: Firenze University Press, 353-377. 
Ljiljana M. Banjanin

\section{CONCERNING SERBOCROATIAN, SERBIAN AND CROATIAN LANGUAGE ASSISTANTSHIPS AND ASSISTANTS IN ITALY}

\section{Summary}

The subject of our study is assistantships for our language as an integral part of Slavic studies in Italian universities. In our introduction we have reviewed, from a historical perspective, those centres for Slavic studies in which our discipline, the Serbocroatian language, was present and was studied during the second half of the 20th century. Then, we presented the evolution and changes in the name of the language following the dissolution of the Yugoslav state, an event which also affected language assistantships. Regarding the latter, we focused on their role in post-reform Italian universities, the academic and legal status of the language assistants and their standing in the Italian university system.

Through a mapping of the universities, we identified the institutes in which the Serbocroatian and/or Serbian and Croatian languages are taught, along with the respective assistantships, in such a way as to produce a clear picture of the position of the Serbian language on Italian university curricula. We conclude that, in comparison with the past, this is marginal and requiring of radical action on the part of the Serbian state and its institutions in order to preserve the language and its teaching abroad through language assistantships.

Key words: Italian slavistics, universities, language assistantships, university reform, exchange language assistants, permanent assistant positions, short-term assistant positions, Serbian language. 